\title{
Why Being Democratic is Just Not Enough: The EU's Governance Transfer
}

Vera van Hüllen and Tanja A. Börzel

Forthcoming in:

Börzel, T. and van Hüllen, V. (2015) Governance Transfer by Regional Organizations:

Patching Together a Global Script. Houndmills, Basingstoke: Palgrave Macmillan.

\section{INTRODUCTION}

The European Union (EU) is a promoter and protector of 'good governance' par excellence.

The Europeanization of its member states and attempts at external governance transfer towards third countries have earned the EU the name of a 'transformative' or 'normative' power (cf. Börzel and Risse 2009; Manners 2006). Yet, in comparison with other regional organizations, the EU has focused on the transformation of domestic governance institutions beyond rather than within its borders. Only recently, has the EU begun to develop policies and instruments that explicitly aim at protecting the very norms and values within its own member states that it has sought to transfer to accession candidates, neighbourhood countries and third states. Not only has the emergence of a comprehensive policy for internal governance transfer lagged behind the establishment of the EU's external policy by ten years. It is also much weaker than the EU's rhetoric and its practice of external governance transfer would suggest. This is all the more puzzling since problems with democratic pluralism, the independence of the judiciary, or minority rights, in both old and new member states, question the extent to which the EU has been effective in promoting and protecting governance standards internally. In order to explain the late and rather weak engagement of the EU in internal governance transfer, we argue that the demand only arose with the prospect of the EU's Eastern enlargement. As a 'club of democracies', the EU did not see the need for internal governance transfer for the longest time. Alternative mechanisms, provided internally by infringement 
proceedings and other instruments at the disposal of the European Commission and externally by the Council of Europe (CoE), were sufficient to protect the 'community of values' of the EU in its early years. It was the impending accession of a large number of new and potentially unstable democracies that created the initial demand for formal provisions to protect standards of democracy, human rights, and the rule of law in the EU. In particular, member states adopted Article 7 of the Amsterdam Treaty to lock in domestic changes in post-communist countries after their accession to the EU and thereby created specific post-accession instruments. In addition, the diffusion of governance transfer by regional organizations in the 1990s provided a supply for modelling the EU's democracy clause and for finally adopting its own Fundamental Rights Charter. Yet, the EU’s provisions for internal governance transfer are much weaker compared to other regional organizations, reflecting the old member states’ unwillingness to grant the EU powers to interfere with issues at the core of their political sovereignty.

The second part of the chapter will outline the puzzle of the EU's delayed and weak internal governance transfer. Since the late 1990s, the EU has institutionalized a number of provisions for protecting democracy, human rights, the rule of law, and good governance in member states. However, lacking systematic monitoring and enforcement mechanisms beyond the 'nuclear option' or Article 7 and the protection of fundamental rights in the implementation of EU law by the European Court of Justice (ECJ), they seem to be symbolic rather than effective instruments. The third part explains the delayed establishment and weak institutional design of the EU's internal governance transfer by the functional demand for locking in democratic changes in the new members and the normative concern for the EU's international legitimacy as a normative power, on the one hand, and the reluctance of old member states to have the EU interfere with their sovereignty over issues of democracy and human rights, on the other. Moreover, regional integration by law has provided the EU with alternative policies and instruments to protect its fundamental values in the member states. 


\section{TOO LITTLE, TOO LATE}

Provisions for governance transfer by the EU vis-à-vis its member states comparable to those of other regional organizations emerged relatively late and remain surprisingly weak until this day. Human rights and democracy have always played a role in the practice of European integration (see below). It was only in the mid-1980s, however, that member states made their first formal commitment to governance transfer within the framework of the EU. The Single European Act (SEA, 1986/1987) obliged member states to 'promote democracy on the basis of the fundamental rights recognized in the constitutions and laws of the Member States’ (preamble, $3^{\text {rd }}$ paragraph) internally and to 'display the principles of democracy and compliance with the law and with human rights' (preamble, $5^{\text {th }}$ paragraph) in its external relations. The commitment to democracy and fundamental rights became legally binding with the EU's founding Maastricht Treaty (1992/1993, article F TEU). At this stage, the EU was still one of the early movers on governance transfer, compared to other (sub-)regional organizations focusing on economic integration (Börzel and Stapel in this chapter). From then on the EU developed a practice of governance transfer in its external relations that focused on 'exporting' the EU's norms of democracy, human rights and the rule of law to third countries around the world (Börzel and Risse 2009; van Hüllen and Börzel 2013). However, it took the EU another decade before it began to tentatively specify and operationalize these standards for governance transfer vis-à-vis its own member states.

It was in the Treaty of Amsterdam (1997/1999) that the EU created its first mechanisms for promoting and protecting 'the principles of liberty, democracy, respect for human rights and fundamental freedoms, and the rule of law' (article 6 TEU) without, however, further specifying the meaning of these principles. Rather, it continued to refer to international law, especially the European Human Rights Convention, and the ‘constitutional traditions’ of member states. 
The Treaty of Amsterdam also translated the commitment to broad governance standards into a formal membership condition (article 49 TEU), thereby essentially enshrining the political Copenhagen Criterion adopted by the European Council in 1993 in the treaties. In addition, EU member states agreed to include a safeguard clause to protect their respect of the Union's basic principles (Article 7 TEU). ${ }^{1}$ Article 7 established a sanction mechanism in case member states failed to uphold these principles, ultimately allowing for the suspension of membership rights of the member state concerned in the event of a 'serious and persistent breach.' With the Nice treaty revision (2001/2003), member states added a prevention mechanism to Article 7, enabling the EU to already act upon a 'clear risk of a serious breach', heading off an erosion of the EU’s principals at an earlier stage (Sadurski 2010: 397; Bogdandy 2000: 1309; Merlingen, et al. 2000: 483). However, the design of Article 7 renders it a rather blunt instrument - an instrument of last resort or a 'nuclear option', but hardly effective for preventing a major crisis through active promotion and protection at an early stage of eroding compliance. While the clause is legally binding and covers the full range of the EU's governance standards, these are extremely vague and imprecise. There is neither a definition nor an operationalization of the values specified in Article 2 TEU, their breach, or the risk thereof. The criteria for the application of Article 7 are, hence, open to political interpretation. Neither is the Article linked to a regular monitoring exercise that would help to systematically determine threats of non-compliance. The European Commission or the European Court of Justice (ECJ) have no role to play in the application of Article 7. Nor did member states link Article 7 to the EU's human rights policies based on the principle of anti-discrimination and the Fundamental Rights Charter (Sadurski 2010: 395; see below). Enforcement is further weakened by high majority requirements. Any decision to apply Article 7 is not left to the member states alone but also requires the consent of the European Parliament, making it necessary to obtain two majorities. Any decision on a risk or a breach has to be supported by a two-thirds majority vote of the European Parliament in addition to agreement among four 
fifths of the EU's member states (minus one) in the Council of the EU or a unanimous decision (minus one) of the European Council respectively. The double majority requirement in both Council and Parliament constitutes an almost insurmountable institutional hurdle for the application of Article 7. Moreover, the lack of sufficiently precise criteria as to what constitutes a serious breach of liberal democratic values adds a further obstacle to building the required majorities.

The strongest mechanism for governance transfer appears to be the EU's anti-discrimination policy, since it works through the EU's supranational decision-making and enforcement procedures. However, it is also extremely limited in scope, focusing on one human rights principle rather than the EU's fundamental rights or other governance standards more broadly. The Treaty of Amsterdam mandates the European Community to 'take appropriate action to combat discrimination based on sex, racial or ethnic origin, religion or belief, disability, age or sexual orientation' (article 13 TEC, now art. 19 TFEU), finally creating a legal basis for earlier practices (Bouget and Prouteau 2002; Ellis and Watson 2012; Geddes and Guiraudon 2004; Bell 2008). As a follow-up to Amsterdam, in 2000 the Council of the EU and the European Parliament adopted the Race and Employment Directives (Heidbreder and Carrasco 2003: 9-10) as well as a second Equal Treatment Directive in 2004, specifying and operationalizing the human rights principle of anti-discrimination through the EU's policymaking process. Also in 1997, the European Monitoring Centre on Racism and Xenophobia (EUMC) was founded, reflecting the EU's growing ambition to develop a human rights policy based on the principle of anti-discrimination. In this field of action, the EU has even engaged in active promotion through Community programmes to combat discrimination (2001-2006) and for employment and social solidarity (PROGRESS, 2007-2013). In the early 2000s, the EU and its member states began to work on specifying their commitment to human rights more broadly, developing the EU's own Charter of Fundamental Rights. The Treaty of Nice referred to the Fundamental Rights Charter, but it only took full 
legal effect as a catalogue of human rights to be respected by the EU and its member states in the application of EU Law with the entry into force of the Lisbon Treaty in December 2009. Moreover, the EU has no comparable ‘catalogue' of standards, not to mention a respective acquis, specifying the other issue areas of democracy, the rule of law, and good governance. Nor is the Charter backed by a systematic monitoring or enforcement mechanism as regards the compliance of member states. Still, it has quickly become a point of reference for the ECJ in judging the conformity of national legislation with human rights as part of EU law (de Búrca 2013). In 2007 the EU created the Fundamental Rights Agency (FRA) as the successor to the EUMC. In contrast to the EU Network of Independent Experts on Fundamental Rights, that the European Commission had established in 2002 (European Commission 2003: 9; Sadurski 2010: 417), the FRA neither has a mandate to systematically monitor member states’ overall compliance with the Charter as a whole nor to monitor their performance with regard to Article 7. In general, the EU's member states were careful to establish no direct link between the Charter, on the one hand, and Article 7, on the other.

Beyond treaty provisions applicable to all member states, the EU started to expand its instruments for governance transfer in the new member states that joined in 2004 and 2007, respectively. It created specific provisions for post-accession assistance and conditionality, targeting new member states only. The so-called 'Transition Facility’ continued financial and technical assistance previously provided under respective pre-accession instruments PHARE and IPA. For those ten new member states that joined the EU in 2004, it encompassed appropriations for three years following accession, amounting to EUR 380 million in 20042006 (article 34 act of accession). For Bulgaria and Romania, who became members in 2007, as well as Croatia, which joined in 2013, it was limited to one year after accession, worth EUR 82 million and EUR 29 million respectively (articles 31 and 30 of the acts of accession). Post-accession financial instruments have financed projects in areas not covered by, for example, the EU’s Structural Funds, including justice and home affair issues such as anti- 
corruption strategies and judicial reform. The individual acts of accession also included a number of safeguard clauses (Trauner 2009: 5). These allowed the adoption of 'appropriate measures' for up to three years after accession in case there were shortcomings in implementing EU law with regard to the internal market and justice and home affairs in the new member states. Building on these safeguard clauses, the European Commission created a specific Cooperation and Verification Mechanism (CVM) for Bulgaria and Romania (Gateva 2010: 6; Trauner 2009: 6; Spendzharova and Vachudova 2012). The CVM was an innovation in that it extended the EU's systematic pre-accession monitoring and reporting system beyond the date of accession for a set of benchmarks that aimed at strengthening an independent judiciary in order to fight corruption and, in the case of Bulgaria, organized crime. In addition to bi-annual progress reports, it includes technical assistance and exchanges of information in order to facilitate compliance.

The EU's emerging post-accession policy is unprecedented, but much weaker than its preaccession instruments in terms of financial aid and incentives and also much more limited in its scope. Conditionality is barely considered effective given that 'the limited penalizing power of the remedial and preventive sanctions established in the framework of the CVM produces a very weak negative incentive structure’ (Gateva 2010: 21). Rather than locking in democratic changes in new member states, 'backsliding is a particular concern because the EU mechanisms for sanctioning members that violate EU democratic principles are relatively weak.' (Levitz and Pop-Eleches 2010: 458).

To sum up, the EU's commitment to governance standards emerged early in the mid-1980s and, with the Maastricht Treaty, covered the whole range of principles characteristic of a liberal democratic governance script. While the EU's move to governance transfer was in line with the global trend, its own rhetoric of a 'community of values' internally and a 'transformative' or 'normative' power externally has raised expectations that it has not met: Neither has the EU been a pace-setter in the global surge of internal governance transfer nor 
has it opted for a particularly strong design promising to be effective in promoting and protecting its standards. Why has the EU been so reluctant to introduce strong mechanisms of internal governance transfer, particularly after it quickly became clear that processes of democratic consolidation in new member states were not irreversible?

\section{THE DEMOCRACY SOVEREIGNTY DILEMMA}

Changes in demand and supply factors after the end of the Cold War can explain well the EU's turn towards internal governance transfer in the second half of the 1990s in view of the pending accession of a large number of new democracies (Börzel and van Hüllen in this volume; Börzel, et al. 2013). For the first 40 years of European integration, there had been no real demand among the EU's member states for regional institutions to formally promote and protect governance standards at the national level. First, even though the founding treaties of the 1950s did not include any reference to democracy, human rights, or the rule of law, the EU has always been a 'community of values' of Western European democracies. The so called 'Birkelbach Report' (Birkelbach 1961), presented in the parliamentary assembly of the European Communities, confirmed already in the early 1960s that membership in and accession to the three European Communities was inextricably linked to the values shared by (potential) member states, including democracy and human rights.

Second, experiencing decades of relative stability and peace, the EU hardly faced any negative externalities arising from coups d'état or massive human rights violations. Greece, Portugal and Spain only became members of the EU once they had completed their transitions to democracy. However, in preparation for this Southern enlargement in the 1980s, the EU's member states for the first time agreed on an informal provision for internal governance transfer. The pending accession of Greece, Portugal and Spain had raised concerns among member states about the safeguarding and strengthening of democratic reforms to lock in their recent transitions. While the Treaties remained unchanged, the European Council issued a Declaration on Democracy in April 1978 stating that 'respect for and maintenance of 
representative democracy and human rights in each Member State are essential elements of membership’ (EC Bulletin 3/1978: 6). The declaration could be invoked by the member states to counteract breaches of democracy after accession (Wallace 1996). It is certainly no coincidence that EU member states included their first formal commitment to democracy and human rights in the SEA in 1986 in light of the three new democracies having joint the EU in the early 1980s.

Third, the EU had early on developed functional equivalents to internal governance transfer through the process of regional integration. The ECJ and the European Commission were instrumental in developing alternatives to formal governance transfer by securing existing standards. Besides monitoring the conformity of national policies with EU primary and secondary law, the ECJ has since the late 1960s protected the respect of human rights and fundamental freedoms in the implementation of Community legislation (Bogdandy 2000: 1320; Heidbreder and Carrasco 2003: 6; Merlingen, et al. 2000: 4). Before the Charter of Fundamental Rights, which did not enter into force until 2009, the ECJ referred to the 'legal heritage of the Community' formed by principles common to all member states (Alston and Weiler 1998: 665). The ECJ thereby permitted individuals to challenge the EU legal acts on the basis that they violated their human rights (ibid.: 709). Moreover, the EU made specific efforts at establishing an anti-discrimination policy. Using 'specific legal bases to be found in the Treaty, where human rights and the objectives of creating a common or single market happen to coincide' (ibdi.: 666), the EU and especially the European Commission sought to advance issues such as gender equality, reflected, for example, in the first Equal Treatment Directive from 1976 (Bogdandy 2000: 1314; Alston and Weiler 1998: 717). Judicial protection of human rights and their promotion through EU secondary law presented functional equivalents to internal governance transfer. However, they emerged as sideproducts of economic integration rather than the intentional efforts of the EU to shape the governance institutions of its member states by developing a general jurisdiction on human 
rights, democracy, and the rule of law (Sadurski 2010: 419; Bogdandy 2000: 1320).

Moreover, these efforts focussed on anti-discrimination policies as a particular dimension of human rights that could be linked to market freedoms (employment) and had, in case of gender equality, their origins in Article 119 of the Treaty of Rome (equal pay).

Finally, the EU did not set its own governance standards. Instead, it referred to the legal heritage of its member states and the Conventions of the CoE. The CoE complemented projects of economic integration and cooperation in Europe, such as the EU and the European Free Trade Area, with a decidedly political dimension, including a well-developed and wellprotected regional human rights regime.

\section{A New Demand for Internal Governance Transfer...}

With the end of the Cold War, the situation changed radically. Dealing with transformation processes in Central and Eastern European Countries (CEEC) and deep ethnic conflict in the Western Balkans was first of all a challenge for the EU's external relations, hence the development of its sophisticated toolbox for external governance transfer. Various policies and instruments were developed through an incremental process of 'learning by doing' rather than a grand master plan. They initially emerged from the EU's development cooperation with the so-called African, Caribbean and Pacific countries, and then 'travelled' to the Eastern enlargement process and to European neighbourhood countries (Börzel, et al. 2007). At the same time, the EU's efforts at external governance transfer since the late 1980s were inextricably linked to the emergence of the EU as an international actor that projected and thus reaffirmed its identity as a 'community of values' through developing the image of a ‘transformative’ or ‘normative’ power (Anderson 2008; Börzel and Risse 2009). However, when the Copenhagen European Council formally granted a membership perspective to the CEEC in 1993, the prospect of the accession of a large number of newly established democracies in the near future generated the demand for formal mechanisms of internal governance transfer among the EU’s old member states. 
Initially, the majority of the EU-15 had been reluctant to open the perspective of membership to 'new' European states. At the same time, they felt a need to welcome the post-communist countries 'home' to Europe. The overlap in membership of the EU and the CoE opened up opportunities for the EU-15 to pursue two diverging but, in the case of the EU, complementary strategies vis-à-vis the CEEC. With the CEEC having been swiftly accepted into the CoE, the old Western European member states used the CoE to reward the CEEC's orientation to the West. Moreover, they could employ the CoE as a 'school of democracy' facilitated by the CoE's traditional approach to socializing its member states into governance standards through dialogue and cooperation (Gawrich in this volume). The EU in turn offered the CEECs a clear membership perspective in 1993. However, it delayed their accession in favour of an extended preparatory period during which it supported adherence to the Copenhagen Criteria and the adoption of the acquis communautaire. Accession conditionalities were to bring potential members up to scratch regarding Western European standards for liberal democratic political systems and market economics before joining the EU, in order to minimize any potentially disruptive effects of enlargement on the integration process. This approach was later continued in form the of the establishment of specific postaccession instruments, which extended conditionality and capacity-building beyond accession, thereby effectively discriminating against the new member states rather than creating inclusive mechanisms that promoted and protected developments in all member states.

The demand generated by the uncertainties of Eastern enlargement looms large in explaining the EU's surge towards internal governance transfer in the late 1990s. It also accounts for the creation of the safeguard clause under Article 7. Such a sanction mechanism had already been prominently proposed in December 1995 in the final report of a Reflection Group and later discussed at the Intergovernmental Conference throughout 1996 (Sadurski 2010: 390). The need for such a clause was regularly justified with reference to Eastern enlargement, 
suggesting that the EU should safeguard its democracy and human rights status quo in anticipation of the accession of new and potentially unstable democracies (ibid.: 391-396; Merlingen, et al. 2000: 5; Dinan 2001: 37).

While applicable to all member states, Article 7 was clearly part of the attempts of the Treaty of Amsterdam to address the need for institutional reforms to prepare the EU-15 for the accession of up to 12 new member states. The addition of the prevention mechanism in the Treaty of Nice (2001), however, was a response to an internal demand that arose from developments inside the old member states. The 1990s saw heightened debates about racism and xenophobia in Western rather than Eastern Europe, fuelled by the rise of right-wing populism and electoral victories of Jean-Marie Le Pen’s Front National in France and, most, prominently, Jörg Haider’s Austrian Freedom Party (Freiheitliche Partei Österreichs, FPÖ) in Austria.

After the Austrian general elections of 1999, Wolfgang Schüssel of the Austrian People’s Party (Österreichische Volkspartei, ÖVP) formed a coalition government with the FPÖ, a right-wing populist party whose politicians and especially its chairman Jörg Haider were known for racist and xenophobic positions. European politicians warned against this step and even before the new government was sworn in, a declaration of the EU Presidency on behalf of the other 14 member states threatened diplomatic sanctions. These unilateral sanctions were indeed applied in February 2000 and affected bilateral relations between Austria and the other EU member states, but not Austria’s representation within the EU. Article 7 did not allow an EU response to the situation in Austria because the inclusion of the FPÖ in the government represented as such no ‘serious and persistent breach’ of the EU’s fundamental principles. However, the wider public and the governments of the other EU member states felt the necessity to act upon their disapproval. It is controversial whether European governments were driven by a concern for the future of democracy and human rights, owing to a specific European sensitivity (Bogdandy 2000: 1318), or whether they were driven by the 'self-interest 
of power-hungry politicians’ (Merlingen, et al. 2001: 61) in light of right-wing parties growing stronger in Western Europe, challenging their own political majorities. After all, 'Haiderism was not an isolated phenomenon in Western Europe at the time' (Sadurski 2010: 399; see also Andreev 2009: 385). Things were not going well for the EU’s selfunderstanding and image - especially given the demanding stance that the EU had developed in its effort to transfer governance in external relations, not least in its pre-accession period but also beyond. For example, a failure to include the respect of minority rights, set by the CoE universally recognized within the EU-15, in the EU's accession conditions quickly led to charges of double standards and hypocrisy (Sadurski 2010: 395; cf. Heidbreder and Carrasco 2003: 16; Albi 2009; Johns 2003).

Finally, the institutionalization of internal governance transfer mechanisms was largely driven by internal demand factors. However, they were met by the supply of an emerging global script for governance transfer by regional organizations in the 1990s (Börzel and Stapel in this volume; Börzel, et al. 2013). With the end of the Cold War, continental organizations, such as the CoE and the Organization of American States, had extended their initial focus on human rights to also prescribe and promote standards related to democracy, the rule of law, and good governance. Similarly, a growing number of regional economic communities outside of Europe also began to engage in (internal) governance transfer, including ECOWAS, SADC, and Mercosur. Yet, compared to these organizations, the institutional design of the EU's standards and instruments appears to be rather weak. It reflects an attempt by old member states to strike a balance between their demand for locking in the democratic and human rights reforms of new members, on the one hand, and unwillingness to give the EU the power to sanction undemocratic practices or human rights violations, on the other.

\section{... but Only Weak Instruments}

In all fairness, the member states of the EU have not had to face any military coups d'état or massive human rights violations. The elaboration of democratic and human rights standards or 
provisions for military coercion to protect them may appear unnecessary. In a regional organization such as the EU, which has a firm democratic membership and a strict preaccession and post-accession conditionality, the suspension of membership rights should be sufficient to prevent the erosion of governance standards. Confining sanctions to serious breaches of democracy, human rights and the rule of law, or the risk thereof, may also reflect the existence of a comprehensive regime of governance transfer at the continental level. The CoE welcomed the accession of the EU to the European Convention of Human Rights, which became possible, and in fact mandatory, after the Lisbon Treaty, granted the EU legal personality (Article 6). It has been wary about the EU building up its own human rights regime with the Charter of Fundamental Rights for concerns about doubling institutions and watering down COE standards (Polakiewicz 2013; Craig 2013; Gragl 2013).

Yet, member states not only designed Article 7 as a 'nuclear option' in terms of its scope. The decision-making rules for its activation are extremely high. These rules have prevented the application of Article 7 even in the two instances in which it might have been considered at all - in the case of concerns about violations of human rights in Hungary in 2010 and Romania in 2012 (Sedelmeier 2014; van Hüllen and Börzel 2013). Nor did member states establish any monitoring mechanisms; the European Commission as the guardian of the treaty is not at all involved in the application of Article 7. Clearly, the (old) member states have done everything to pursue the prevailing self-interest of consolidated democracies in protecting their domestic sovereignty when it comes to constitutive as opposed to regulatory issues (Moravcsik 2000: 244-245).

Rather than a functional demand for effectively protecting and promoting governance standards within the EU, the introduction of a democracy or safeguard clause seemed to be driven by normative concerns of the (old) member states to avoid double standards for old and new members, on the one hand, and the international legitimacy of the EU as a normative power, on the other. If there was a functional demand for protecting governance standards, it 
has been satisfied by resorting to alternative instruments to respond to situations that raise concerns regarding (potential) member state violations of the EU's fundamental values. The use of infringement proceedings, for example against France for expelling Roma as a violation of the free movement of persons (van Hüllen and Börzel 2013), or other instruments at the European Commission's disposal is not only a way of circumventing party politics blocking majorities in the Council of the EU and the European Parliament. It also corresponds to the European Commission's institutional self-interest and self-understanding as the guardian of the treaties. Framing issues in terms of non-conformity of national policies and practices with EU law is also in line with its strategy, together with the ECJ, to invoke EU legislation aimed at the creation of the Single European Market to protect and promote human rights.

In sum, Article 7 would allow the EU to engage in internal governance transfer beyond the scope of Community legislation. Yet, instead of activating the potential of this broad mandate, the EU continues to rely on its traditional approach of ensuring the respect of fundamental rights in the implementation of European policies and developing a narrower human rights policy based on the principle of anti-discrimination. Relying on the EU's elaborate preaccession policy for supporting and stabilizing the political and economic transformation in the Central and Eastern European accession candidates, the old member states chose to opt for rather weak provisions that would signal the EU's commitment to its governance standards, paying tribute to normative expectations generated by its identity as a normative power, the diffusion of global script, and the need to avoid double standards, all while protecting their sovereignty from interferences through supranational mechanisms. Their preference for a rather weak institutional design aligned with the institutional self-interest of regional actors, such as the European Commission and the CoE, in strengthening their own sition in alternative settings for governance transfer. 
Unlike other regional organizations, the EU initially focused on shaping the governance institutions of third countries and accession candidates rather than member states. Only with its 'big bang' Eastern enlargement, did the EU turn the patchwork of individual Community policies and the judicial protection of the fundamental rights of its 'market citizens' into a more comprehensive approach of internal governance transfer aimed at locking in democratic standards in new but eventually also in old member states. Next to the post-accession instruments based on conditionality and assistance, the EU has strengthened the constitutionalization of the very principles it has sought to protect and promote externally; its new anti-discrimination legislation and the Charter of Fundamental Rights do not only bind EU institutions but also the member states when they apply and enforce EU Law. Moreover, Article 7 and the Fundamental Rights Agency provide sanctioning and monitoring mechanisms that apply equally to old and new member states.

While these policies and instruments certainly provide a basis for internal governance transfer, they focus on human rights and the rule of law rather than democratic standards. Moreover, (old) member states have been reluctant to allow for an effective monitoring of compliance with the principles enshrined in Article 2 and protected by Article 7. There are no instruments in place that would match the toolbox the EU has developed in its external democracy promotion and protection frameworks. As a result, the internal dimension has largely remained confined to the protection of democratic and human rights which had evolved from a 'spill-over' effect of Community legislation aimed at creating the Single European Market, as we could observe it in the fields of environmental and social regulation or Justice and Home Affairs (Börzel 2006). Unsurprisingly, EU member states have been criticized for using double standards, being 'very willing to police human rights and democracy in their eastern backyard - but less interested in having European institutions nosing about in their own affairs’' (Sadurski 2010: 395; cf. Heidbreder and Carrasco 2003: 16; Albi 2009; Johns 2003). 
While acting as a pace-setter in external governance transfer, the EU's attempts to shape the governance institutions of its member states are even less remarkable in a global comparison of governance transfer by regional organizations. This should not be too surprising since the EU has always been a community of democracies. Democracy has always been a condition for joining the EU. The Europeanization of domestic structures by adopting the acquis communautaire and integrating into the Single European Market was considered sufficient to ensure that new member states converged with the governance standards of the old ones (Whitehead 1996). The EU’s approach to internal governance transfer only changed with Eastern enlargement, when the EU took on 10 new democracies in Central and Eastern Europe. Not least due to the rise of right-wing populist parties in the EU-15, the mechanisms the EU had primarily installed to safeguard democratization in the new member states spilled over, making all member states equally subject to democracy protection and promotion policies.

Member state governments have been very reluctant to accept the control of the EU over their democratic institutions. Given their limited demand, the EU's attempts at internal governance transfer still appear modest and remain driven by the European Commission and the ECJ, seeking to protect the fundamental rights of EU citizens through individual Community policies. Yet, despite the resistance of the member states against the implementation of a comprehensive approach that would mirror its external governance transfer, the EU is no real laggard when compared to other regional organizations: Going beyond formal provisions for governance transfer, European integration provides an institutionally dense environment with a web of obligations and enforcement mechanisms that might be more effective than political declarations and formal procedures - a proposition that not only the increasing democratic backsliding by Hungary, the best pupil in the class of the CEEC, is putting to the test. The Euro crisis has revealed severe problems in Greece, Italy, Portugal, and Spain regarding compliance with the EU's governance standards. Enlargement and the Euro crisis may give 
new impetus for EU powers on democracy, human rights, and the rule of law. The European Commission recently launched an initiative for a European Public Prosecutor and monitoring powers for the rule of law in member states. It remains to be seen whether member states will be able to maintain their resistance against more centralized mechanisms of internal governance transfer, particularly given the damage current developments are doing to the EU’s international legitimacy as a normative power.

\section{NOTES}

1 The Lisbon Treaty changed the text into 'values of respect for human dignity, freedom, democracy, equality, the rule of law and respect for human rights, including the rights of persons belonging to minorities' (Article 2 TEU Lisbon). 